\title{
Geogebra Pada Aplikasi Sigil sebagai Pengembangan E-Modul Pembelajaran Matematika
}

\author{
Riska Fitriana ${ }^{1}$, Achi Rinaldi ${ }^{2}$, Suherman $^{3}$ \\ ${ }^{1,2}$ Universitas Islam Negeri Raden Intan Lampung \\ ${ }^{3}$ University of Szeged Hungary \\ *riskafitriana932@gmail.com
}

\begin{tabular}{|l|l|l|l|} 
Received: $14-07-2020$ & Revised: 01-05-2021 & Accepted: 04-05-2021 & Published: 06-06-2021 \\
\hline
\end{tabular}

\begin{abstract}
ABSTRAK
Penelitian pengembangan ini bertujuan untuk mengetahui kelayakan e-modul pembelajaran matematika berbasis aplikasi sigil berbantuan geogebra pada peserta didik SMP/MTs kelas VIII, dan untuk mengetahui respon peserta didik dan pendidik terhadap e-modul pembelajaran matematika berbasis aplikasi sigil berbantuan geogebra. Jenis penelitian yang dilakukan adalah dengan metode penelitian dan pengembangan (R\&D) dengan menggunakan model 4D (Define, Design, Development, Disseminate). Instrumen yang digunakan pada penelitian ini, yaitu non tes. Instrumen-instrumen ini diberikan sesuai dengan subjek pada penelitian pengembangan. Teknik analisis data yang dilakukan adalah analisis data kualitatif dan analisis data kuantitatif yang diperoleh dari hasil validasi ahli materi, ahli media, dan ahli bahasa, serta respon peserta didik,dan respon guru terhadap bahan ajar e-modul pembelajaran matematika pada materi lingkaran SMP kelas VIII. Hasil dari kelayakan oleh validator ahli materi, ahli media, dan ahli bahasa terhadap $e$ modul memperoleh kriteria sangat layak digunakan, dan hasil kemenarikan $e$-modul yang diperoleh dari data angket peserta didik dengan jumlah 80 responden, terdiri dari uji kelas kecil, dan kelas besar memperoleh kriteria sangat menarik. Sehingga dapat disimpulkan e-modul pembelajaran matematika berbasis aplikasi sigil berbantuan geogebra pada peserta didik SMP/MTs kelas VIII pada materi lingkaran memberikan hasil yang baik dan layak untuk digunakan.
\end{abstract}

Kata Kunci: E-modul, Sigil, GeoGebra.

\section{ABSTRACT}

The purpose of this study was to determine the feasibility of e-module mathematics learning based on geogebra-assisted sigil applications in class VIII SMP / MTs students, and to determine the responses of students and educators to e-module mathematics learning based on geogebra-assisted sigil applications. This type of research is the research and development $(R \& D)$ method using the 4D model (Define, Design, Development, Disseminate). These instruments are given according to the subject on development research. The data analysis technique used is qualitative data analysis and quantitative data analysis obtained from the validation results of material experts, media experts, and linguists, as well as student responses, and teacher responses to e-module learning mathematics teaching materials in class VIII SMP circle material. The results of the eligibility by material expert validators, media experts, and linguists on the e-module obtained a final score of 3.7 with very suitable criteria, and the results of e-module attractiveness were obtained from questionnaire data of students with a total of 80 respondents, consisting of small class test, and large class obtained an average score of 3.6 with very attractive criteria. So it can be concluded that the e-module of mathematics learning based on geogebra-assisted sigil applications for SMP / MTs class VIII students on circle material gives good results and is feasible to use.

Keywords: E-module, Sigil, GeoGebra-assisted. 


\section{PENDAHULUAN}

Teknologi informasi dan komunikasi (TIK) mempunyai potensi sebagai sarana untuk mengembangkan ketrampilan dan pengetahuan dalam proses pembelajaran (Mocanu dan Deaconu, 2017). Suasana proses pembelajaran secara aktif dapat mengembangkan potensi agar memiliki kekuatan spiritual keagamaan, kepribadian, kecerdasan, dan ketrampilan yang dibutuhkan untuk dirinya dan sekitarnya. Selain itu belajar secara menyeluruh dapat diartikan sebagai suatu aktivitas yang memperoleh ketrampilan dan pengetahuan (Utami, Jatmiko, dan Suherman 2018). Oleh sebab itu agar keterampilan peserta didik dalam proses pembelajaran dapat meningkat harus dilakukannya perubahan yang dapat menunjang majunya pembelajaran (Ismuwardani, Nuryatin, dan Doyin 2019) . Perkembangan masa dari yang mulanya menggunakan media cetak berangsur-angsur ke media digital (Restendy 2020; Tazkiyyaturrohmah 2018).

Hal tersebut berpengaruh pada dunia pendidikan, terutama dalam penyajian media pembelajaran yang sudah memanfaatkan media digital, tidak hanya terbatas media cetak (Cikarge dan Utami 2018; Winatha 2018). Salah satu contoh penyajian tersebut ialah $e$ book yang termasuk versi elektronik dari sebuah buku cetak, untuk membacanya dibutuhkan perangkat elektronik dan software pembuka khusus (Ardiyanta, Sudjimat, dan Partono 2014; Ruddamayanti 2019; Winaya, Darmawiguna, dan Sindu 2016). Adapun adanya inovasi dalam pengembangkan bahan ajar dalam pembelajaran didorong oleh adanya perkembangan teknologi e-book (Rahmawati 2019; Rezalia Dewi 2017; Rosida, Fadiawati, dan Jalmo 2017; Yumarni 2019). Bahan ajar yang dapat ditransformasikan penyajiannya kedalam bentuk elektronik salah satunya modul elektronik, yang dirancang sebagai alat pembelajaran secara elektronik, berisi materi menarik dan sistematis untuk mencapai suatu kompetensi yang diharapkan (Imansari dan Sunaryantiningsih 2017; Satriawati 2015; Winarko 2013).

Pada dasarnya modul elektronik mengadaptasi karakteristik, format dan bagianbagian modul cetak pada umumnya. Sigil Softwere ialah aplikasi editor yang digunakan untuk format E-Pub yang bersifat open source yang mudah digunakan oleh semua penulis dan pembaca (Darma dkk. 2019). Aplikasi sigil dibutuhkan untuk mengembangkan sebuah buku digital yang mudah digunakan secara gratis (Nafiáh, Mashuri, dan Wijaya 2019)

Selain menggunakan handphone saat pembelajaran, banyak peserta didik yang tidak menggunakan handphone secara tepat sebagai penunjang, sehingga kasus terbanyak saat pembelajaran matematika peserta didik menggunakan handphone saat pembelajaran 
tetapi bukan sebagai penunjang pembelajaran mereka lebih suka membuka aplikasi Facebook, WhatsApp, Instagram dan aplikasi lainnya (Apriyanto dan Hilmi 2019; Hanifah, Supriadi, dan Widyastuti 2019). Maka Pengembangan e-modul ini dilakukan untuk menambah referensi yang telah ada dan lebih memudahkan peserta didik dalam memahami mata pelajaran matematika (Laili 2019; Wijayanti dkk. 2016). Selain itu diharapkan dengan dikembangkannya e-modul ini peserta didik dapat meminimalisir penggunaan handphone untuk aktivitas yang tidak diinginkan sehingga peserta didik bisa lebih focus, aktif dan praktis (M. Pratama, Johari, dan Marzal 2018).

Pemanfaatan media pembelajaran pada hakekatnya bertujuan untuk meningkatkan efisiensi dan efektivitas pengajaran (Mauladaniyati dan Kurniawan 2018a). Dengan bantuan media, peserta didik diharapkan menggunakan sebanyak mungkin alat inderanya untuk mengamati, mendengar, merasakan, meresapi, menghayati dan pada akhirnya memiliki sejumlah pengetahuan, sikap dan keterampilan sebagai hasil belajar. E-Modul termasuk salah satu media yang efisien, dan efektif yang mengutamakan kemandirian peserta didik. Memasuki erateknologi telah banyak teknologi yang baru dan dapat memberikan informasi yang lebih banyak (Koparan 2017). Perkembangan teknologi yang berkembang seiring zaman (Astria 2019; Hidayat 2015; R. A. Pratama, Ulfa, dan Kuswandi 2018; Rahmawati 2018). Teknologi yang semakin mudah didapat, dan canggih dengan harga yang terjangkau saat ini pada umumnya modul disajikan dalam bentuk cetak, oleh sebab itu dengan menggunakan teknologi elektronik dapat disajikan dalam bentuk digital dan dapat disebut E-Modul (Fausih 2015; Larasati dkk. 2020).

Penelitian yang relevan dengan penelitian ini diantaranya Penelitian yang dilakukan (Ula dan Fadila 2018) yaitu Melalui metode research and development (R\&D) dibuat mengembangkan E-Modul Berbasis Learning Content Development System Pokok Bahasan Pola Bilangan SMP. Berdasarkan hasil olah data angket respon peserta didik pada uji coba skala kecil dan uji lapangan skala besar, e-modul matematika yang dikembangkan dalam kriteria interpretasi kemenarikan sangat menarik sebagai sumber bahan belajar dan layak digunakan. Pemilihan aplikasi sebagai pendukung dalam pembuatan e-modul yang dikembangkan dikarenakan perkembangan teknologi, sehingga menyebabkan penggunaan bahan ajar yang paling tepat adalah modul elektronik. Modul elektronik dapat digunakan sebagai alat bantu mengajar karena media audio visual merupakan media yang memiliki unsur gerakan dan suara. Dapat disimpulkan bahwa hasil akhir pengembangan e-modul berbasis Learning Content Development System ini layak digunakan sebagai bahan ajar matematika pada materi pola bilangan. Selain itu penelitian lainnya yang dilakukan 
(Mardiah, Widyastuti, dan Rinaldi 2018) Hasil pengembangan yang dilakukan oleh peneliti ini adalah menghasilkan Modul pembelajaran matematika berbsis etnomatematika menggunakan metode inkuiri, Respon guru terhadap modul yang dikembangkan diperoleh rata-rata skor $86,15 \%$ dengan kriteria sangat menarik. Respon siswa terhadap modul diperoleh rata-rata skor $87,28 \%$ dengan kriteria sangat menarik. Jadi modul pembelajaran matematika berbasis etnomatematika menggunakan metode inkuiri siap digunakan sebagai bahan ajar.

Penelitian lainnya oleh (Yuswanti 2020) Hasil pengembangan yang dilakukan oleh peneliti ini adalah menghasilkan Bahan ajar e-modul teks eksplanasi untuk kelas XI SMK Bratas Karangkates berbasis Sigil ini menggunakan pola yang dikembangkan Dick \&Carey dengan penyesuaian oleh penulis. Langkah pengembangan dilakukan dalam beberapa kegiatan, yaitu 1) penelitian pendahuluan, (2) perancangan produk, (3) pengujian internal, (4) uji coba kelompok kecil, (5) uji coba kelompok besar. Penelitian lainnya yang dilakukan oleh (Andriani, Dewi, dan Halomoan 2018) proses pengembangan modul berupa buku dan strategi pembelajaran matematika dilakukan sampai dengan tahap 3 yaitu define, design, development. Tahap design menghasilkan draf 1, kemudian pada tahap pengembangan draf 1 yang divalidasi oleh 3 validator dan direvisi sesuai dengan komentar ahli kemudian menghasilkan draf 2, kemudian draf 2 diuji kelompok kecil yang menghasilkan kecepatan keterbacaan yang baik, selanjutnya uji coba kelompok besar menghasilkan nilai kepraktisan dan keefektifan yang baik.

Penelitian ini berbeda dengan penelitian sebelumnya yang hanya menggunakan aplikasi sigil untuk membuat emodul tanpa berbantuan geogebra, dan belum ada yang menerapkan pada materi lingkaran, dimana penelitian ini akan mengembangkan e-modul dengan menggunakan aplikasi sigil berbantuan geogebra pada materi lingkaran, dimana dengan menggunakan aplikasi sigil terdapat soal-soal evaluasi yang dapat dijawab didalam e-modul tersebut sehingga dapat melihat peserta didik apakah telah memahami materi yang diberikan, penelitian ini memiliki tujuan yaitu untuk mengetahui kelayakan e-modul pembelajaran matematika berbasis aplikasi sigil berbantuan GeoGebra pada peserta didik SMP/MTs, dan untuk mengetahui respon pendidik dan peserta didik terhadap e-modul pembelajaran matematika berbasis aplikasi sigil berbantuan GeoGebra pada peserta didik SMP/MTs.

\section{METODE PENELITIAN}


Jenis penelitian yang dilakukan adalah dengan metode penelitian dan pengembangan (R\&D. E-Modul pembelajaran matematika berbasis Aplikasi sigil berbantuan Geogebra. produk tersebut agar dapat berfungsi didalam masyarakat luas, maka dibutuhkan sebuah penelitian untuk menguji keefektifan produk yang dihasilkan. Produk E-Modul pembelajaran matematika berbasis Aplikasi Sigil menggunakan GeoGebra dalam proses pembelajarannya. Lokasi penelitian yang dipilih adalah MTs Negeri 1 Bandar Lampung dan MTs Negeri 2 Bandar Lampung.

Waktu penelitian yaitu pada tahun ajaran 2019/2020, populasi penelitian yaitu seluruh peserta didik kelas VIII Mts N 1 Bandar Lampung dan MTs N 2 Bandar Lampung, dan sampel yang digunakan yaitu kelompok kelas kecil terdiri 10 peserta didik dan kelas besar terdiri 30 peserta didik pada masing-masing Sekolah, yaitu berjumlah 80 peserta didik. Penelitian yang dikembangkan ini menggunakan model pengembangan Thiagarajan dengan langkah-langkah penelitian dan pengembangan model 4D (Uyun, Holisin, dan Kristanti 2017). Keempat tahap sebagai berikut:

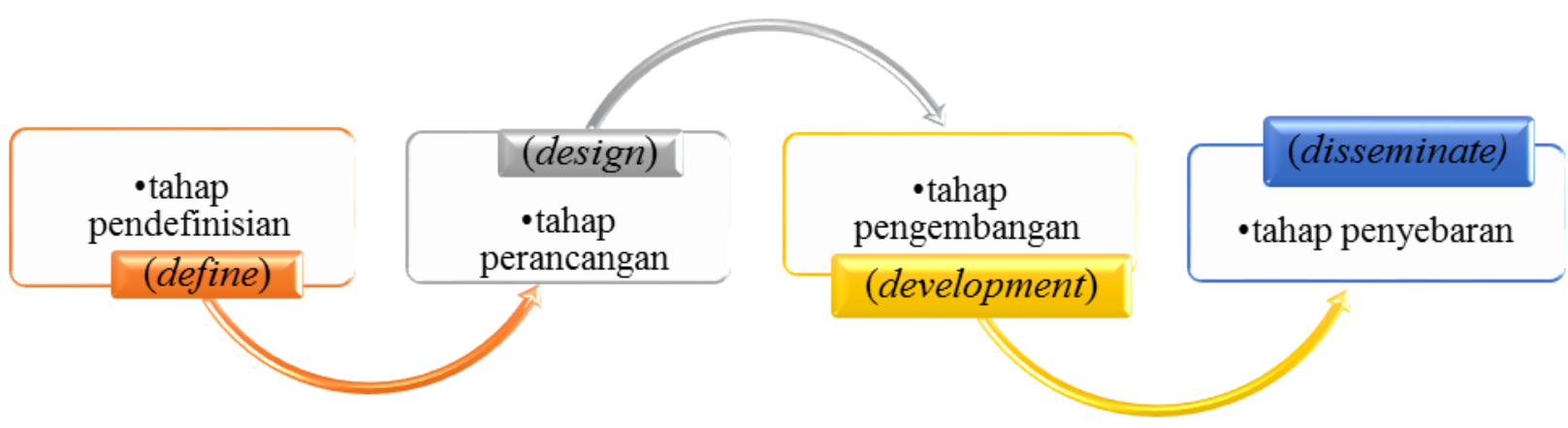

Gambar 1. Alur Model Pengembangan 4D Thiagarajan (Sumber: Thiagarajan, 1974)

Uraian keempat tahap beserta komponen-komponen 4-D Thiagarajan yaitu: Tahap Pendefinisian (define) Pada tahap pendefinisian bertujuan menetapkan dan mendefinisikan kebutuhan-kebutuhan pembelajaran yang terfokus pada analisis terhadap situasi yang dihadapi guru, karakter peserta didik, konsep-konsep yang akan diajarkan, dan diakhiri dengan tujuan pembelajaran, tahap Perancangan (design) Tujuan dari tahap ini adalah merancang perangkat pembelajaran, sehingga diperoleh prototype (perangkat pembelajaran contoh). Tahap ini dimulai setelah ditetapkan tujuan pembelajaran khusus, Tahap Pengembangan (development) Pada tahap ini bertujuan untuk menghasilkan perangkat pembelajaran yang direvisi berdasarkan masukan para ahli dan data yang diperoleh dari uji coba. Kegiatan pada tahap ini adalah penilaian para ahli, dan uji coba lapangan, kemudian tahap Penyebaran (dessiminate) Tahap ini merupakan tahap penggunaan perangkat yang telah dikembangkan pada skala yang lebih luas, misalnya dikelas lain, disekolah lain oleh 
guru yang lain (Prayitno 2017). teknik pengumpulan data dalam penelitian ini melalui: wawancara pra penelitian, angket, dan dokumentasi . Teknik analisis data yang dilakukan pada penelitian ini adalah analisis data kualitatif dan analisis data kuantitatif. Analisis kualitatif diperoleh dari hasil wawancara juga kritik saran yang diberikan validator ahli pada saat melakukan validasi/ uji kelayakan dan analisis kuantitatif diperoleh dari hasil validasi ahli materi, ahli media, dan ahli bahasa, serta respon peserta didik,dan respon guru terhadap bahan ajar E-Modul pembelajaran matematika pada materi lingkaran SMP kelas VIII.

\section{HASIL PENELITIAN DAN PEMBAHASAN}

Pengembangan yang dihasilkan oleh penelitian ini adalah menghasilkan Bahan Ajar E-Modul dengan berbasis Aplikasi Sigil berbantuan Geogebra. Penelitian ini berdasarkan tahap pengembangan menggunakan model pengembangan oleh Thiagajaran yaitu model 4D dengan 4 tahapan yaitu; tahap pendefinisian (define), perancangan (design), pengembangan (development), penyebaran (disseminate), keempat tahapan tersebut disajikan dalam grafik berikut ini:

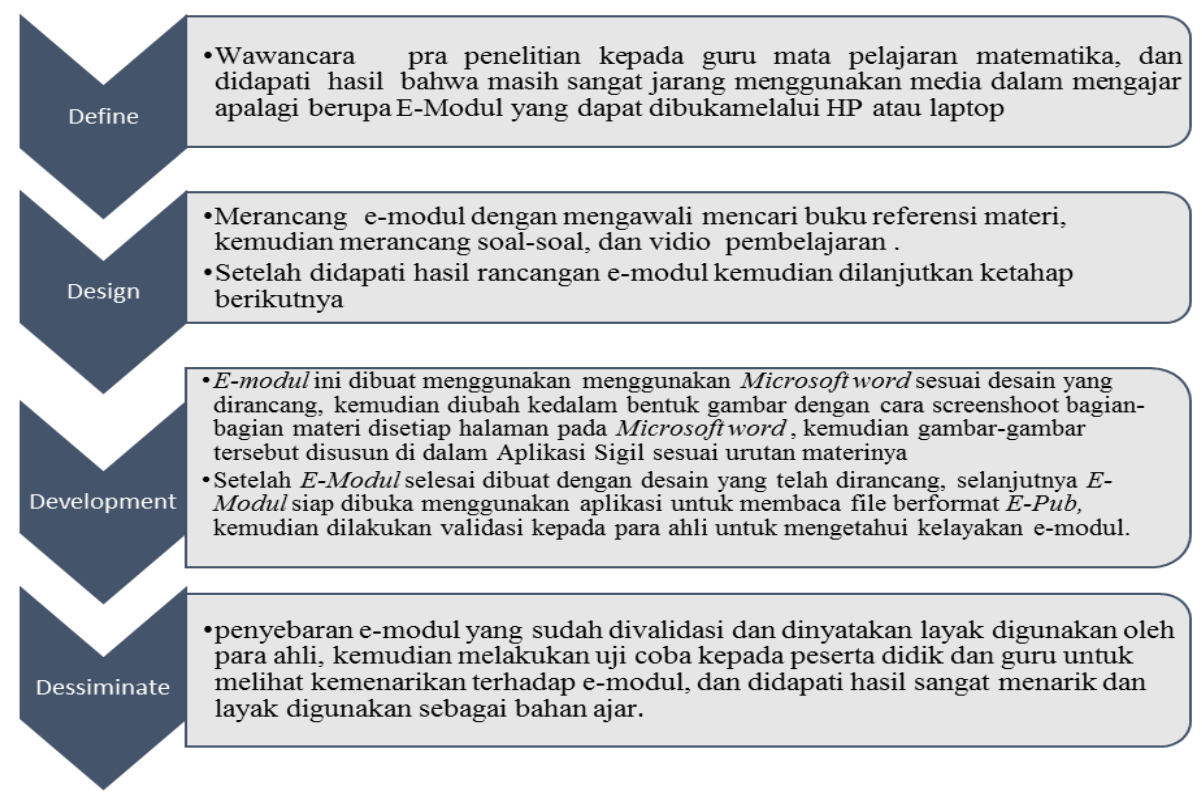

Gambar 2. Grafik Hasil Tahapan 4D

Tahapan pertama dalam proses penelitian adalah sebuah identifikasi masalah. Peneliti melakukan identifikasi masalah dengan pra penelitian di MTs $\mathrm{N} 1$ Bandar Lampung dan MTs N 2 Bandar Lampung, dalam pengumpulan data yang pertama yaitu melakukan observasi di sekolah dan melakukan pengamatan kegiatan belajar di dalam kelas, setelah itu penulis melakukan wawancara kepada guru mata pelajaran matematika 
dimasing-masing sekolah untuk mengetahui permasalahan dan kebutuhan didalam pembelajaran, selain itu juga penulis melakukan penyebaran angket analisis kebutuhan kepada peserta didik untuk mengetahui apa saja yang dibutuhkan dalam pembelajaran agar tepat sasaran. Setelah mendapatkan data awal, kemudian penulis mencari penelitianpenelitian yang telah dilakukanoleh peneliti terdahulu, karena untuk meyakinkan pembaca terhadap penelitian yang akan dikembangkan oleh penulis. Peneliti mencari hasil penelitian mengenai bahan ajar e-modul pembelajaran matematika, aplikasi sigil, kemudian mengenai berbantuan geogebra.

Peneliti menggunakan model penelitian Thiagajaran dengan langkah-langkah penelitian dan pengembangan model 4D. Keempat tahap berikut adalah tahap pendefinisian (define), tahapperancangan (design), tahap pengembangan (development), dan tahap penyebaran (disseminate). Tahapan yang pertama yaitu tahap pendefinisian (define), tahapan dalam pendefinisian ini adalah analisis awal akhir, analisis peserta didik, analisis konsep, analisis tugas, dan perumusan tujuan pembelajaran. Setelah melakukan analisis didapati peserta didik mengharapkan bahan ajar untuk menunjang pembelajaran dikelas dengan memanfaatkan teknologi, dan fasilitas agar dalam proses pembelajaran, peserta didik mampu memahami materi yang disampaikan dengan mudah.

Setelah menganalisis masalah dan kebutuhan yang ada di sekolah, tahapan berikutnya yaitu tahap perancangan (design). Bagian dari bahan ajar yang telah di desain yaitu cover, identitas singkat penulis, daftar isi, glosarium, pendahuluan yang terdiri dari: identitas modul, deskripsi, petunjuk penggunaan modul, kemudian kegiatan pembelajaran, contoh soal, serta latihan disetiap bagian pembelajaran, dan evaluasi, kemudian daftar pustaka. Penulis juga membuat instrumen penilaian para ahli materi, ahli bahasa, ahli media, dan peserta didik, kemudian pendidik/guru berupa angket penilaian produk.Angket penilaian yang diberikan kepada para ahli adalah untuk menilai kelayakan bahan ajar $e$ modul, sedangkan angket yang diberikan kepada peserta didik, dan pendidik/guru untuk mengetahui respon peserta didik, dan pendidik/guru terhadap bahan ajar e-modul matematika yang telah dikembangkan.

Selanjutnya adalah tahap pengembangan (development) yang berisi tentang kegiatan mewujudkan perancangan produk yaitu pembuatan e-modul pembelajaran, penilaian para ahli, dan uji coba pertama.Dalam pembuatan e-modul ini penulis memperoleh materi dari beberapa referensi dari buku pembelajaran matematika, kemudian penulis merangkum materi dari beberapa referensi, agar materi mudah dipahami oleh peserta didik.Materi yang disajikan dalam e-modul ini adalah materi lingkaran, karena 
menurut penulis materi tersebut sulit dipahami oleh peserta didik karena masih kurangnya media atau bahan ajar yang menarik yang dapat membantu pendidik dalam menyampaikan materi. Setelah $e$-modul selesai dibuat, kemudian dilakukan penilaian para ahli materi, ahli bahasa, ahli media. Dalam penelitian ini terdapat 6 validator yaitu: 2 dosen matematika untuk ahli materi, 2 dosen matematika untuk ahli media, dan 2 guru mata pelajaran bahasa indonesia SMP untuk ahli bahasa. Kemudian para ahli melakukan review e-modul dengan mengisi angket penilaian, untuk menentukan kelayakan dan kevalidan produk agar dapat digunakan untuk diujikan kepada peserta didik. Revisi dilakukan beberapa kali hingga $e$ modul benar-benar dinyatakan layak oleh validator.

Perbandingan hasil validasi dari ahli materi, ahli media, ahli bahasa ditampilkan dalam grafik berikut ini:

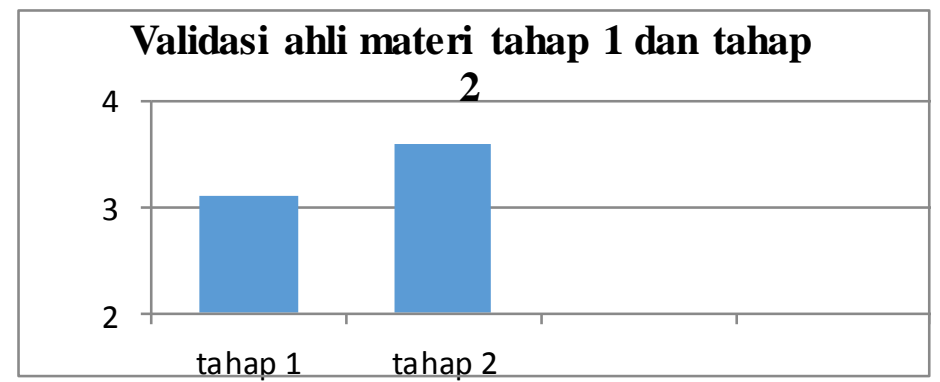

Gambar 3. Perbandingan Validasi Ahli Materi Tahap 1 dan Tahap 2

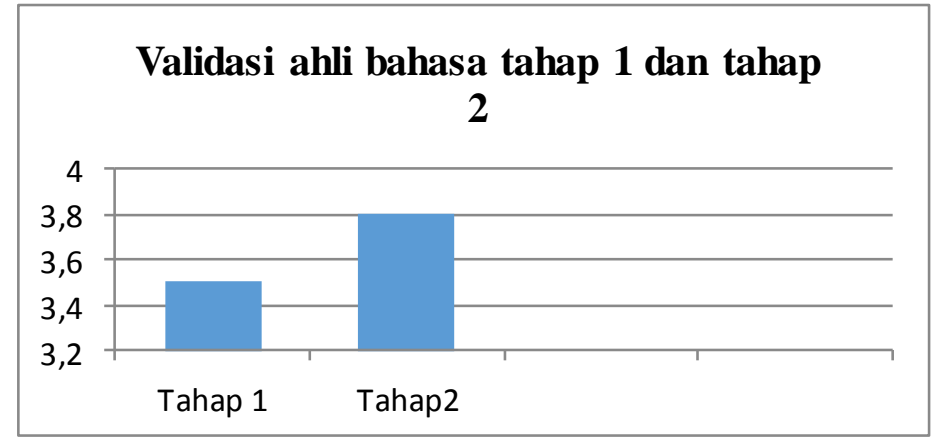

Gambar 4. Perbandingan Validasi Ahli Bahasa Tahap 1 dan Tahap 2

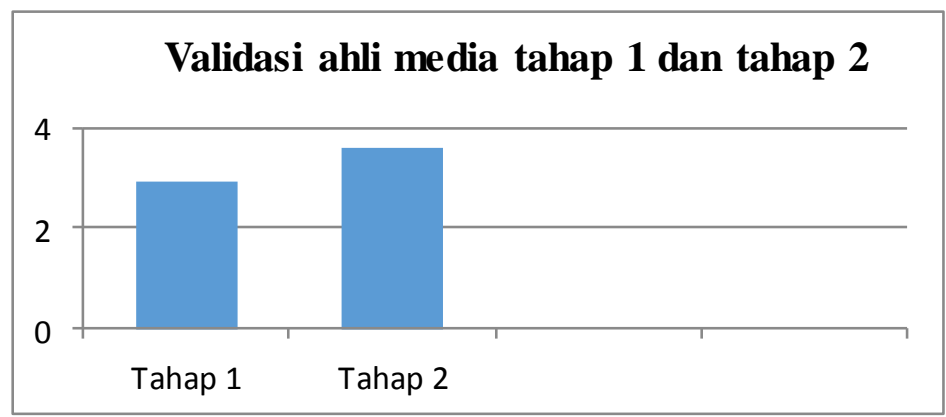

Gambar 4. Perbandingan Validasi Ahli Bahasa Tahap 1 dan Tahap 2 
Aspek penilaian ahli materi mencakup kelayakan isi, dan kelayakan penyajian. Revisi yang diberikan adalah Titik pusat lingkaran tidak konsisten menggunakan $\mathrm{O}$ atau $\mathrm{P}$, dan gambar tidak rapih, dan gunakan font times new roman dalam setiap titik pada lingkaran. Setelah materi selesai direvisi sesuai dengan saran dan masukan validator, kemudian setiap validator mengisi angket yang kedua yaitu angket setelah revisi. Hasil akhirnya diperoleh 3,6 dinyatakan "layak digunakan", sehingga produk yang dikembangkan oleh penulis layak digunakan dalam proses pembelajaran. Aspek penilaian ahli bahasa mencakup kelayakan kebahasaan.Revisi yang diberikan adalah, bahasa yang digunakan kurang komunikatif sehingga materi masih sulit untuk dipahami.Setelah kebahasaan selesai direvisi sesuai dengan saran dan masukan validator, kemudian setiap validator mengisi angket yang kedua yaitu angket setelah revisi. Hasil akhirnya dinyatakan 3.7 "layak digunakan", sehingga produk yang dikembangkan oleh penulis layak digunakan dalam proses pembelajaran. Aspek penilaian ahli media mencakup kelayakan kegrafikan, dan seluruh desain isi didalam e-modul. Revisi yang diberikan yaitu Table of contents dihilangkan, kemudian setiap link pada daftar isi dipergunakan fungsi nya.Setelah media selesai direvisi sesuai dengan saran dan masukan validator, kemudian setiap validator mengisi angket yang kedua yaitu angket setelah revisi, hasil akhirnya dinyatakan 3.9 "layak digunakan", sehingga produk yang dikembangkan oleh penulis layak digunakan dalam proses pembelajaran.

Setelah produk direvisi dan dinyatakan layak digunakan oleh validator, artinya emodul pembelajaran sudah dapat diujikan kepada peserta didik. Kemudian penulis melakukan ujicoba pertama kepada peserta didik dalam skala kecil berjumlah 10 peserta didik di MTs N 1 Bandar Lampung, dan MTs N 2 Bandar Lampung, untuk mendapatkan hasil pengamatan terhadap $e$-modul yang telah dinyatakan layak, melalui angket respon peserta didik yang diisi menggunakan google form. Berdasarkan hasil ujicoba pertama ini mendapatkan respon positif dari peserta didik dengan kriteria "sangat menarik" pada uji coba pertama (kelas kecil). Pada penelitian ini uji coba pertama (kelas kecil) menggunakan 1 kelas peserta didik MTs N 1 Bandar Lampung dan 1 kelas peserta didik MTs N 2 Bandar Lampung, kemudian dipilih 10 peserta didik dari masing-masing sekolah secara random, sehingga total responden pada uji coba pertama ini berjumlah 20 peserta didik.

Setelah dilakukan penilaian para ahli dan uji coba pertama, kemudian tahap selanjutnya yaitu, tahap penyebaran (disseminate) yang merupakan tahap penggunaan 
bahan ajar $e$-modul yang telah dikembangkan dan layak digunakan dalam skala yang lebih luas. Tahap penyebaran ini melibatkan peserta didik dan sekolah yang sama dengan uji coba kelas kecil, dengan jumlah yang lebih banyak yaitu 30 peserta didik dari masingmasing sekolah, sehingga jumlah responden dalam uji coba kelas besar ini adalah 60 peserta didik. Perbandingan hasil uji coba dan uji coba lapangan disajikan dalam grafik berikut:

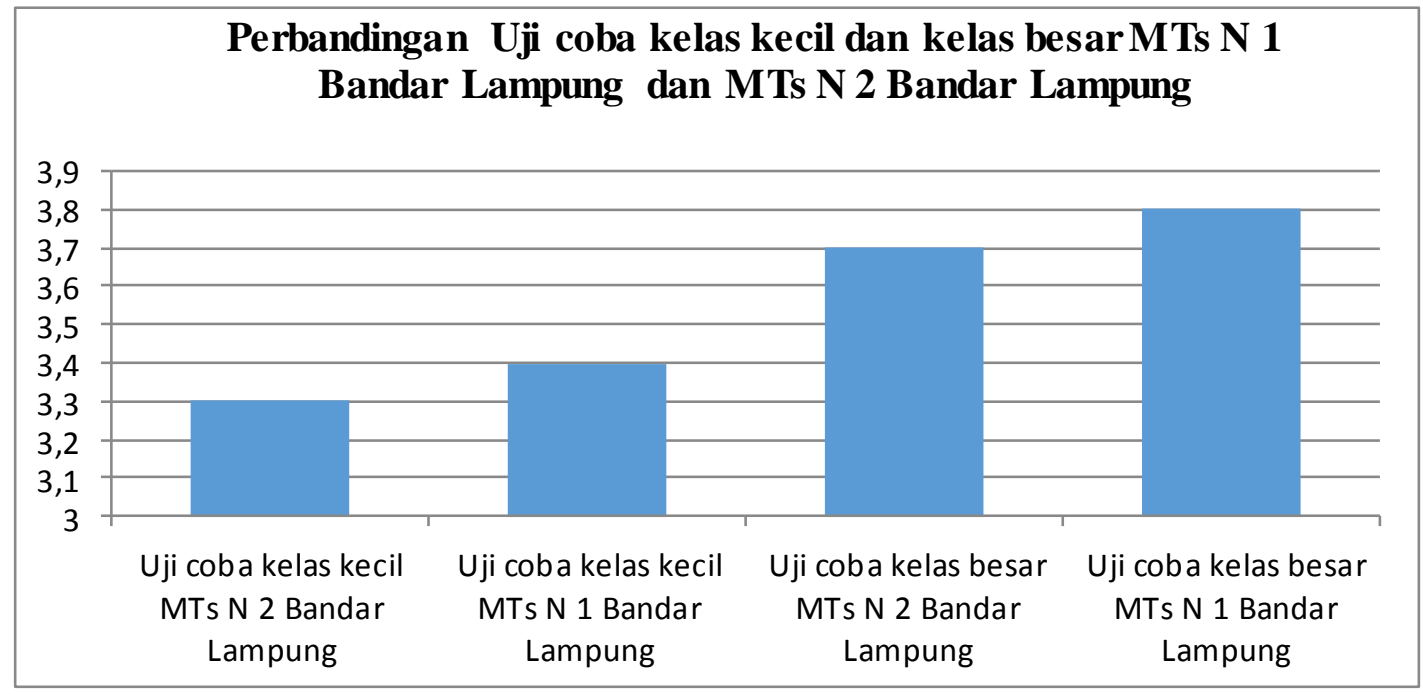

Gambar 5. Perbandingan Uji Kelas Kecil dan Kelas Besar Mts N 1 Bandar Lampung dan Mts N 2 Bandar Lampung

Penelitian dilakukan secara online atau daring baik pada uji coba kelas kecil, maupun ujicoba kelas besar, dengan cara peneliti membuat grup telegram dengan para peserta didik serta pendidik/guru mata pelajaran matematika, kemudian peneliti mengirimkan file e-modul melalui telegram, kemudian peserta didik diarahkan oleh peneliti untuk mendownload aplikasi epub reader untuk membuka e-modul yang diberikan, setelah peserta didik membuka emodul tersebut, lalu peneliti mengirimkan link google form yang berisikan angket respon peserta didik dan angket respon pendidik/guru untuk diisi oleh peserta didik, dan pendidik/guru.

Selama proses penelitian terdapat beberapa hambatan dikarenakan dilakukan secara daring atau online, maka respon peserta didik sedikit lama sehingga dalam penelitian yang hanya mengisi angket melalui google form ini memakan waktu yang cukup lama, hingga peserta didik benar-benar mengisi angket tersebut waktu yang dibutuhkan peneliti yaitu 2 pekan dalam 2 sekolah tersebut. Berdasarkan hasil olah data angket respon peserta didik dan pendidik/guru dari uji kelas kecil dan kelas besar, $e$ modul pembelajaran yang dikembangkan termasuk ke dalam kriteria "sangat menarik" sehingga produk tersebut layak digunakan untuk belajar dikelas maupun belajar mandiri. 
Bahan ajar berupa $e$-modul pembelajaran matematika yang dikembangkan ini dinilai layak dan menarik disebabkan menggunakan aplikasi sigil yang terdapat vidio pembelajaran, dan materi yang dijelaskan pun mudah dipahami peserta didik, dan dalam fitur aplikasi sigil terdapat soal evaluasi yang dapat langsung dikerjakan oleh peserta didik dengan langsung mengklik pilihan jawaban yang telah disediakan, sehingga peserta didik dapat dengan mudah mengevaluasi diri setelah materi yang disampaikan tersebut selesai dijelaskan oleh guru, dalam aplikasi sigil pun dapat diakses dengan mudah melalui berbagai alat elektronik seperti; handphone, laptop, tablet, dan lainnya. Menggunakan format epubsehingga peserta didik dapat menggunakan aplikasi sigil dengan mudah karena file epub akan menyesuaikan ukuran $e$-modul sesuai dengan alat elektronik yang digunakan, selain itu dengan adanya format Epubpada aplikasi sigil lebih memudahkan peserta didik untuk membaca isi $e$-modul secara acak atau secara yang diinginkan dengan ketersediaan daftar isi .

Sehingga peserta didik akan lebih mudah menggunakan aplikasi sigil sebagai sarana yang mudah untuk belajar. Hal ini sesuai dengan penjelasan pada penelitian yang dilakukan (Liana, Ellianawati, dan Hardyanto 2019) yaitu dijelaskan bahwa e-modul interaktif berbasis android menggunakan sigil softwere adalah modul dalam bentuk digital, yang terdiri dari teks, gambar, vidio pembelajaran, dan uji kompetensi, sehingga membuat peserta didik lebih interaktif dalam pembelajaran. Senada dengan penelitian yang dilakukan oleh (Abidin dan El Walida 2017) dijelaskan bahwa pengembangan $e$ modul interaktif adalah bahan ajar yang dapat mengarahkan peserta didik dalam belajar secara kreatif, aktif, sistematik, dan efektif sehingga dapat memperoleh pengetahuan dan pemahaman materi secara maksimal.

Penelitian yang relevan dengan penelitian ini diantaranya adalah sebagai berikut: Penelitian yang dilakukan oleh (Safitri 2015) bahwa E-Modul layak digunakan dalam pembelajaran matematika dapat dilihat dari Hasil belajar peserta didik pada kelompok eksperimen media e-modul dengan pendekatan pembelajaran matematika realistik berbantuan flipbook maker pada materi bangun ruang sisi datar lebih baik dibandingkan dengan peserta didik yang mendapat pembelajaran konvensional pada kelompok kontrol dalam pembelajaran matematika pada bangun ruang sisi datar kelas VIII Semester 2 di MTs. Penelitian oleh (Mauladaniyati dan Kurniawan 2018) yaitu Pemanfaatan geoenzo sebagai media pembelajaran matematika dengan pendekatan kontekstual untuk meningkatkan pemahaman geometri diperoleh hasil pretest dan posttest yang dilakukan di kelas eksperimen dan kelas kontrol, kemudian hasil analisis yang dilakukan mendapatlan 
hasil yang baik, sehingga pemanfaatan media pembelajaran dengan aplikasi geozebo efektif dijadikan sebagai bahan ajar dalam pembelajaran. Penelitian (Wijayanti dkk. 2016) Dari Hasil validitas muka terhadap e-book dalam kategori valid dengan konsistensi tanggapan internal (reliabilitas) dari kedua pakar dengan menggunakan uji Gregory berada pada kategori sangat konsisten yaitu 100\%. Hasil lebih efektif jika dibandingkan dengan hasil belajar kelas kontrol yang tidak menggunakan $e$-book.

Hasil baru yang diperoleh dari penelitian ini terhadap beberapa penelitian yang relevan yaitu, penelitian ini menghasilkan produk bahan ajar berupa modul berbentuk elektronik dengan materi lingkaran yang telah divalidasi oleh para ahli dan sudah diuji cobakan oleh peserta didik dan guru pengampu mata pelajaran matematika sebagai responden kemenarikan bahan ajar, dan hasil dari uji coba produk bahan ajar berupa Emodul pembelajaran matematika berbantuan geogebra layak digunakan.

\section{KESIMPULAN}

Kelayakan produk dilihat pada hasil dari validator ahli materi, ahli media, dan ahli bahasa diperoleh nilai rata-rata akhir dengan kriteria layak digunakan tanpa revisi. Sehingga $e$-modul pembelajaran matematika berbasis aplikasi sigil berbantuan geogebra ini dapat digunakan, kemenarikan produk dilihat dari respon peserta didik dan respon pendidik/guru pada uji coba pertama, dan uji coba kelas besar terhadap produk yang dikembangkan mendapat kriteria sangat menarik, dan uji coba kepada pendidik/guru mendapat kriteria sangat menarik. Dengan demikian e-modul pembelajaran matematika berbasis aplikasi sigil berbantuan geogebra ini sangat menarik dan layak digunakan dalam proses pembelajaran.

\section{REFERENSI}

Andriani, Ade, Izwita Dewi, dan Budi Halomoan. (2018). Development of Mathematics Learning Strategy Module, Based on Higher Order Thinking Skill (Hots) To Improve Mathematic Communication And Self Efficacy On Students Mathematics Department. Journal of Physics: Conference Series 970 (Maret): 012028.

Apriyanto, M. Tohimin, dan Rivan Azizul Hilmi. (2019). Media Pembelajaran Matematika (Mobile Learning) Berbasis Android. Dalam Seminar \& Conference Proceedings of UMT.

Ardiyanta, Anggara Sukma, Dwi Agus Sudjimat, dan Partono Partono. (2014). Pemanfaatan Buku Sekolah Elektronik Sebagai Bahan Ajar Guru Program Produktif Sekolah Menengah Kejuruan. Teknologi dan Kejuruan: Jurnal teknologi, Kejuruan dan Pengajarannya 35 (2). 
Astria, Nurfajrin. (2019). Essay Kajian Kronologis Dan Dampak Penggunaan Dan Perkembangan Teknologi Informasi. Jurnal Inovasi 13 (1).

Cikarge, Ghia Pisti, dan Pipit Utami. (2018). Analisis dan Desain Media PEmbelajaran Praktik Teknik Digital sesuai RPS. Elinvo (Electronics, Informatics, and Vocational Education) 3 (1).

Darma, Rio Sandhika, Ahdika Setyadi, Insih Wilujeng, Jumadi, dan Heru Kuswanto. (2019). Multimedia Learning Module Development Based on SIGIL Software in Physics Learning. Journal of Physics: Conference Series 1233 (Juni): 012042.

Fausih, Moh. (2015). Pengembangan Media E-Modul Mata Pelajaran Produktif Pokok Bahasan 'Instalasi Jaringan Lan (Local Area Network)' Untuk Siswa Kelas XI Jurusan Teknik Komputer Jaringan di SMK Nengeri 1 Labang Bangkalan Madura. Jurnal Mahasiswa Teknologi Pendidikan 5 (3).

Hanifah, Hanifah, Nanang Supriadi, dan Rany Widyastuti. (2019). Pengaruh Model Pembelajaran E-learning Berbantuan Media Pembelajaran Edmodo Terhadap Kemampuan Pemecahan Masalah Matematis Peserta Didik. NUMERICAL: Jurnal Matematika dan Pendidikan Matematika.

Hidayat, Riki. (2015). Analisis Manajemen Penyiaran di Era Teknologi Informasi (Konvergensi Media). Konvergensi 1 (1).

Imansari, Nurulita, dan Ina Sunaryantiningsih. (2017). Pengaruh penggunaan e-modul interaktif terhadap hasil belajar mahasiswa pada materi kesehatan dan keselamatan kerja. VOLT: Jurnal Ilmiah Pendidikan Teknik Elektro 2 (1).

Ismuwardani, Zakiyah, Agus Nuryatin, dan Mukh Doyin. (2019). Implementation of Project Based Learning Model to Increased Creativity and Self-Reliance of Students on Poetry Writing Skills. Journal of Primary Education 8 (1).

Koparan, Timur. (2017). Analysis of Teaching Materials Developed by Prospective Mathematics Teachers and Their Views on Material Development. Malaysian Online Journal of Educational Technology 5 (4).

Laili, Ismi. (2019). Efektivitas Pengembangan E-Modul Project Based Learning Pada Mata Pelajaran Instalasi Motor Listrik. Jurnal Imiah Pendidikan dan Pembelajaran 3 (3).

Larasati, Anggia Dwi, Agil Lepiyanto, Agus Sutanto, dan Triana Asih. (2020). Pengembangan E-Modul Terintegrasi Nilai-Nilai Islam Pada Materi Sistem Respirasi. Didaktika Biologi: Jurnal Penelitian Pendidikan Biologi 4 (1).

Liana, Yeni Rima, Ellianawati Ellianawati, dan Wahyu Hardyanto. (2019). Pengembangan E-Modul Interaktif Berbasis Android Menggunakan Sigil Software pada Materi Listrik Dinamis. Dalam Prosiding Seminar Nasional Pascasarjana (PROSNAMPAS), 2:92632.

Mardiah, Siti, Rany Widyastuti, dan Achi Rinaldi. (2018). Pengembangan Modul Pembelajaran Matematika Berbasis Etnomatematika Menggunakan Metode Inkuiri. Desimal: Jurnal Matematika 1 (2): 119-26.

Mauladaniyati, R., dan D. Kurniawan. (2018a). GeoEnzo Utilization as Mathematics Learning Media with Contextual Approach to Increase Geometry Understanding. Journal of Physics: Conference Series 1132 (November): 012035.

Mauladaniyati, R, dan D Kurniawan. (2018b). GeoEnzo Utilization as Mathematics Learning Media with Contextual Approach to Increase Geometry Understanding. Journal of Physics: Conference Series 1132 (November): 012035.

Mocanu, Elena Madalina, dan Alecxandrina Deaconu. (2017). The Use of Information and Communication Technology (ICT) as a Teaching Method in Vocational Education and Training in Tourism. Acta Didactica Napocensia 10 (3). 
Pratama, Miko, Asni Johari, dan Jefri Marzal. (2018). Pengembangan E-Modul Biologi Berbasis Potensi Daerah Kerinci pada Materi Plantae dan Animalia. Edu-Sains: Jurnal Pendidikan Matematika dan Ilmu Pengetahuan Alam 7 (2).

Pratama, Ramadhana Agung, Saida Ulfa, dan Dedi Kuswandi. (2018). Mobile Learning Berbasis Game Based Learning Pelajaran Matematika Pokok Bahasan Bangun Ruang Sisi Datar. Jurnal Pendidikan: Teori, Penelitian, dan Pengembangan 3 (6).

Prayitno, Trio. (2017). Pengembangan Petunjuk Praktikum Mikrobiologi Program Studi Pendidikan Biologi. Biota 3 (Januari): 31.

Rahmawati, Nurul Alifah. (2018). Penggunaan teknologi informasi dalam pelayanan sumber informasi di perpustakaan. LIBRIA 9 (2).

Rahmawati, Septi. (2019). Pengembangan Bahan Ajar Ebook Pada Mata Pelajaran Praktikum Akuntansi Lembaga Berbasis Kontekstual Untuk Smk. Jurnal Pendidikan Akuntansi (JPAK) 7 (3).

Restendy, Mochammad Sinung. (2020). Dinamika Produksi Media Cetak Dan Tantangan Industri Pers Di Indonesia. Al-Ittishol: Jurnal Komunikasi dan Penyiaran Islam 1 (2).

Rezalia Dewi, Devita. (2017). Pengembangan Bahan Ajar E-Book Interaktif Materi Jurnal Khusus Akuntansi Perusahaan Dagang Berbasis Scientific Approach Sebagai Sumber Belajar Alternatif Kelas XI SMK Negeri 2 Buduran Sidoarjo. Jurnal Pendidikan Akuntansi (JPAK) 5 (2).

Rosida, Rosida, Noor Fadiawati, dan Tri Jalmo. (2017). Efektivitas penggunaan bahan ajar e-book interaktif dalam menumbuhkan keterampilan berpikir kritis siswa. Jurnal Pembelajaran Fisika 5 (1).

Ruddamayanti, Ruddamayanti. (2019). Pemanfaatan Buku Digital Dalam Meningkatkan Minat Baca. Dalam Prosiding Seminar Nasional Program Pascasarjana Universitas Pgri Palembang. Vol. 12.

Safitri, Ida. (2015). Pengembangan E-Module Dengan Pendekatan Pembelajaran Matematika Realistik Berbantuan Flipbook Maker Pada Materi Bangun Ruang Sisi Datar Kelas Viii Smp. AKSIOMA: Jurnal Matematika dan Pendidikan Matematika 6 (2).

Satriawati, Helna. (2015). Pengembangan E-Modul Interaktif sebagai Sumber Belajar Elektronika Dasar Kelas X SMKN 3 Yogyakarta. Skripsi. UniversitasNegeri Yogyakarta.

Sanusi, A. M., Septian, A., \& Inayah, S. (2020). Kemampuan Berpikir Kreatif Matematis dengan Menggunakan Education Game Berbantuan Android pada Barisan dan Deret. Mosharafa: Jurnal Pendidikan Matematika, 9(September), 511-520.

Septian, A., Darhim, \& Prabawanto, S. (2020). Mathematical representation ability through geogebra-assisted project-based learning models. Journal of Physics: Conference Series. https://doi.org/10.1088/1742-6596/1657/1/012019

Tazkiyyaturrohmah, Rifqy. (2018). Eksistensi Uang Elektronik Sebagai Alat Transaksi Keuangan Modern. Muslim Heritage 3 (1).

Ula, Iin Rahmatul, dan Abi Fadila. (2018). Pengembangan E-Modul Berbasis Learning Content Development System Pokok Bahasan Pola Bilangan SMP. Desimal: Jurnal Matematika 1 (2).

Utami, Taza Nur, Agus Jatmiko, dan Suherman Suherman. (2018). Pengembangan Modul Matematika Dengan Pendekatan Science, Technology, Engineering, And Mathematics (STEM) Pada Materi Segiempat. Desimal: Jurnal Matematika 1 (2): 165-72.

Uyun, Qurrotul, Iis Holisin, dan Febriana Kristanti. (2017). Pengembangan Media Handout Segitiga dengan Model Problem Based Instruction. MUST: Journal of Mathematics Education, Science and Technology 2 (1). 
Wijayanti, Ni Putu Ayu, Luh Putu Eka Damayanthi, I. Made Gede Sunarya, dan I. Made Putrama. (2016). Pengembangan E-Modul Berbasis Project Based Learning pada Mata Pelajaran Simulasi Digital untuk Siswa Kelas X Studi Kasus di SMK Negeri 2 Singaraja. Jurnal Pendidikan Teknologi dan Kejuruan 13 (2).

Winarko, Adhin Setyo. (2013). Pengembangan Modul Elektronik Berbasis Poei (Prediksi, Observasi, Eksperimen, Interpretasi) Pada Materi Sistem Indra Kelas Xi Sma Negeri 3 Ponorogo. INKUIRI: Jurnal Pendidikan IPA 3 (01).

Winatha, Komang Redy. (2018). Pengembangan E-modul Interaktif Berbasis Proyek Mata Pelajaran Simulasi Digital. Jurnal Pendidikan Teknologi dan Kejuruan 15 (2).

Winaya, I. Kadek Adi, I. Gede Mahendra Darmawiguna, dan I. Gede Partha Sindu. (2016). Pengembangan E-Modul Berbasis Project Based Learning pada Mata Pelajaran Pemrograman Web Kelas X di SMK Negeri 3 Singaraja. Jurnal Pendidikan teknologi dan kejuruan 13 (2): 198-211.

Yumarni, Asmara. (2019). Inovasi Pembelajaran Pendidikan Agama Islam (PAI) Berbasis Teknologi Informasi. JOEAI: Journal of Education and Instruction 2 (2): 112-26.

Yuswanti, Tutut Umi. (2020). Pengembangan Modul Elektronik Menggunakan Sigil Materi Teks Eksplanasi Untuk Siswa Kelas Xi Di Smk Brantas Karangkates 8 (1). 